\title{
The USE of the coaching collection of metaphorical associative cards «SUPERvision» as ONe of the possible INSTRUMENTS Of PROFESSiONAl SUPPly of psychologists
}

Hrinchenko O. M. The use of the coaching collection of metaphorical associative cards "Supervision" as one of the possible instruments of professional supply of psychologists / O. M. Hrinchenko // Problems of Modern Psychology : Collection of research papers of Kamianets-Podilskyi National Ivan Ohiienko University, G. S. Kostiuk Institute of Psychology of the National Academy of Educational Sciences of Ukraine / scientific editing by S. D. Maksymenko, L. A. Onufriieva. - Issue 40. - KamianetsPodilskyi : Aksioma, 2018. - P. 95-104.

O. M. Hrinchenko. The use of the coaching collection of metaphorical associative cards "Supervision" as one of the possible instruments of professional supply of psychologists. The article considers the peculiarities of the use of the couching deck of the metaphorical associate cards (MAC) «Supervision» as one of the tools that will help future psychologists, as well as existing psychologists, in the process of solving topical issues in the field of professional activities.

It is described that the use of MAC is the newest method for determining topical information about the internal state, as well as personal experiences, which can be solved by analyzing associative images that arise while working with associative cards. It is shown that associative cards are a universal instrument of work that is suitable for use in the professional activities of specialists in the psychological profile.

The content of the author's deck of metaphorical associative cards «Supervision» is presented, reflecting the composition of the professional activity of the psychologist, the basic requirements of the profession to the personality of the professional, the leading spheres of his life, and also listing the emotional states and psychological experiences of the person, required for in-depth work with proposed associative cards.

The exercises and possible ways of working with the mentioned MAC deck are suggested, which we recommend to use for the purpose of training of professional skills in the process of developing the necessary profes- 

sional qualities of a psychologist in the work of both practicing and future specialists in the psychological profile.

Key words: metaphorical associative cards, psychology, students, training, practicing psychologist, supervision.

О. М. Грінченко. Використання коучингової колоди метафоричних асоціативних карт «Супервізія» як одного 3 можливих інструментів професійного супроводу психологів. У статті розглянуто особливості застосування коучингової колоди метафоричних асоціативних карт (далі -МАК) «Супервізія» як одного з інструментів, що допоможе майбутнім психологам, а також психологам-практикам, які вже працюють, у процесі вирішення актуальних питань у сфері професійної діяльності.

Описано, що застосування МАК є новітнім методом визначення актуальної інформації щодо внутрішнього стану, а також виокремлення переживань особистості, які можна вирішити шляхом аналізу асоціативних образів, що виникають під час роботи з асоціативними картами. Показано, що асоціативні карти є універсальним інструментом роботи, який підходить для використання у професійній діяльності фахівців психологічного профілю.

Представлено зміст авторської колоди метафоричних асоціативних карт «Супервізія», що відображають склад професійної діяльності психолога, основні вимоги професії до особистості професіонала, провідні сфери його життя, а також містять перелік емоційних станів і психологічних переживань особистості, необхідних для поглибленої роботи із запропонованими асоціативним картами.

Запропоновано вправи та можливі способи роботи із зазначеною колодою МАК, які ми рекомендуємо використовувати з метою навчання професійно важливим навичкам і розвитку необхідних професійних якостей психолога в роботі як з практикуючими, так і майбутніми фахівцями психологічного профілю.

Ключові слова: метафоричні асоціативні карти, психологія, студенти, навчання, практичний психолог, супервізія.

Statement of the problem in general form. Social and economic changes in modern society put increased requirements to the professional training of psychologists-specialists and, accordingly, the support of the work of practicing psychologists. This fact determines the search and use of the latest methods and techniques in educational, diagnostic and corrective work both with existing professionals and with future specialists in the psychological profile. That is why we pay a particular attention to the use of metaphorical associative cards (MAC), because this is a relatively new (slightly over 40 years old) method of psycho-diagnosis that can be used in any field of human activities, both in the diagnostic phase, when 
there are questions, doubts, the need of clarification and specification of the request, and directly in the process of corrective work. The history of MAC begins with the development in 1970 of the Deck of ON cards as a "psychological game», which was designed to help people understand the others and themselves. For the first time, the "ON" cards were published in Canada in 1981, and then in Germany and Holland in 1986. Subsequently, they were finalized and translated into seventeen languages of the world. Since then, the creation and use of MAC has gained popularity, there are a large number of decks of various associative cards, which continue to develop the ideas laid down in the ON cards, and extend and diversify their scope, methods of engagement, and so on.

Today, MAC is a very popular kind of projective techniques that can quickly and clearly get information about the person, his inner state and experience, identify issues that need to be addressed, and also see the correlation of internal associative images with external life realities. This versatile tool is also suitable for use in professional activities by professionals working with people, primarily psychologists. We pay a special attention in our work, first of all, to the question of the formation of future psychologists during the studies in higher educational establishments, the detection of complications during professional development, and it is precisely in order to diversify and modernize this activity that they have created a coaching deck of metaphorical associative cards "Supervision" from the purpose of its use as an auxiliary in the process of professional self-determination and the formation of future specialists of the specified profile. The advantage of using MAC is also that they should be used in individual work and in the group (collective), as well as in profile groups with representatives of any age.

Analysis of recent researches and publications. The work with MAC is becoming more and more popular in the world today, although its history origins from an event that took place in 1975, when psychotherapist M. Egetmeyer used mini-paintings by Canadian artist E. Raman who created the first «ON» deck to promote conducting a more frank conversation with their clients. Today, this method of work is successfully used in Ukraine by O. Morozovska, R. Tkach, V. Inzhyr, H. Popova, N. Miloradova, in RussiaL. Talpis, N. Nekliudova, O. Kopytina, O. Rasskazova, in Belarus O. Horobchenko, L. Stepanova and others.

Specialists working with metaphorical cards emphasize that the MAC has a deep theoretical basis. This is the theory of free 
associations of Z. Freud, and his view of a human as the unity of three elements: the natural self - the bearer of carnal desires - the subconscious mind, the rational self - consciousness, the moral self - the superscience; and the concept of archetypes referred to by K. G. Jung, who, by the way, suggested explaining the question of history through the prism of the unconscious activity of the human soul and the words-incentives appealing by M. Wertheimer and D. Klein in their experiments on the motivation of the individual, and the notion of representation (the reflection on this is a significant and key phenomenon in human life and the condition of his / her actions, we can find in the landmark A. Schopenhauer's book «The World of Will and Submission»).

The purpose of the article. In our work, we pay a particular attention to the optimization of work on solving professional selfdetermination issues and the identity of future and working psychologists with the help of a new universal instrument of work with metaphorical associative cards.

Presenting main material. One of the means of optimization in the process of self-determination of students-psychologists is the use of metaphorical associative cards. In our opinion, MAC is a rather young and interesting method, which, of course, will interest modern psychology students. Today, MACs are used in trainings, interactive conversations, in individual and group counseling, in organizing group interaction, and so on. This work is carried out in order to identify existing problem issues and find solutions to them and is implemented by identifying and analyzing the associations of everyone engaged in the process of interpreting images on cards. Metaphorical associative cards are one of the tools that are a kind of projective technique that allows you to identify not only the feedback of everyone involved in the process of interpreting an image on a card, but also allows you to track issues that are important to a participant, identify problem points, find ways to the solution of certain issues. And sometimes in the process, one can simply identify and understand a particular issue that was concerned about a person, but it was not clearly articulated. When looking at the image on the card, different people give their interpretation of what they see. Everyone focuses on the moment being the closest to him. Everyone, describing the image, actually shows his inner understanding, the emphasis is on his own experiences. Therefore, one and the same drawing can be differently interpreted by different people. 
Moreover, the interpretation of one and the same image can be different for one person, if it is applied to him when changing the life situation, or when a picture is offered a word or a statement about the combination of which it is necessary to make the impression by comparing this picture with them. And then it is offered to perform the same task by adding other words or statements to the drawing. Metaphorical cards allow you to get the right information about a person, his inner state, and experiences quickly and visually, and identify issues that need to be addressed. Associative cards allow one to see the correlation of a person with different ideas, images of internal and external realities. Cards seem to launch a mechanism for finding answers to problematic issues, helping to find the way for their solution.

The co-educational package of metaphorical associative cards «Supervision» proposed by us is aimed at working with any personal and professional issues and issues that are relevant to the individual at this time. That is why it can be used as a means of supervising work with psychologists conducting practical work, as well as a coaching method in working with future specialists (studentspsychologists).

Description of the deck. The couching deck of metaphorical associative cards «Supervision" is a set of 135 cards, which is divided into two parts. The first part consists of 45 cards, which contain images that reflect and illustrate the composition of the professional activities of the psychologist. The second part includes 90 cards with a list of the corresponding number of words-names of emotional states and psychological experiences of the person, which are aimed at promoting a more in depth disclosure of the proposed images. On the cards containing the image, the types of practical activities of psychologists (counseling psychologist, psychologisttrainer, psychotherapist, military psychologist, family psychologist, zoo psychologist, etc.) are illustrated, drawings depicting types of clients and requests with which they turn to the psychologist are presented (depression, interpersonal relationships, psychological dependence, suicidal thoughts, etc.), the leading spheres of human life (professional, educational, family, etc.), emotional states, experiences, mood (loneliness, despair, mistrust, self-assurance) etc. are presented. Some of the images represent a schematic representation of the types of social interaction and personal situation in society. The second part of the deck (90 cards) contains a verbal list of 
emotional states and psychological experiences (for example, anger, sociability, sadness, interest, love, hate, etc.). Investigators offer a set of cards containing test images. Investigators are invited to choose cards with images and words and analyze the peculiarities of their own perception of the obtained combinations, in accordance with the formulated personal request or actual, but not completely conscious question (experience).

In total 4050 possible combinations of cards from these two parts of a deck can be formed. A large number of possible combinations of pictures and words stimulates the processes of imagination and self-knowledge, promotes the development of creative perception, and also allows to analyze the content of interpretations that arise. The personality explains relying on the system of his / her images, the questions come to the fore, which are directly important, relevant and require a quick solution. Students-psychologists can solve issues related to the problems of professional self-identification, as well as gain experience in working with another form of diagnosis. Practicing psychologists can work with deep, subconscious images and experiences reflecting problems in the professional field that are relevant to a person at the moment. Therefore, we emphasize that associative cards are a valuable and interesting tool that makes it possible:

- to outline and identify the range of problems that have arisen in the professional field;

- to conduct a projective analysis of metaphorical images that arise during work;

- to determine dominant, more weighty problems on the defined issue;

- to reveal the main problem in the field of professional choice;

- to identify ways to solve actual problems;

- to follow the basic laws of formation and development and professional way;

- based on own experience, to activate internal personal resources;

- to implement a dialogue between the internal state and the outside world, to bring to the fore deep, hidden problems;

- to create favorable and comfortable conditions for self-disclosure and self-knowledge.

Metaphorical associative cards (MACs) are an easy, but very interesting and meaningful projective method in which there are no 
right or wrong answers, winners or losers, which in turn allows you to develop communication skills and perceptions, stimulates the ability to listen and express your own thoughts, contributes to development of communicative functions.

Instructions for use. The principle of working with MAC is that, when looking at the image on the map, each person gives his interpretation of what he sees, and also focuses on the actual issue for him. That is, describing the image, he shows his internal experiences. Therefore, one and the same picture can be interpreted differently by different people. Moreover, the interpretation of one and the same image can be different for one person, if it is applied to him when changing the living situation, or when the image is offered to be compared with a certain word, when combined with which a new impression is formed or if the previous meaning is clarified or new meaning is obtained.

The ease of work with MAC is that it is made in a playing form. Considering the drawings and correlating with the suggested words, they remove protective psychological mechanisms, promote the disclosure of feelings and significantly increase the level of openness. As a result, the person becomes open, and in his explanations he subconsciously relies on the system of their own, personally meaningful images, resulting in the foreground issues that are directly relevant, and, as a rule, require an urgent solution. It is extremely important that, first of all, this involves the subconscious, which becomes a driving mechanism in describing their experiences, feelings, etc.

There is a large number of ways to work with MAC, which are also useful in working with the deck «Supervision». In work with psychologists, as we have repeatedly pointed out, issues of professional development related to professional self-identification, selfidentification and the creation of a professional "Image of $\mathrm{Me}$ " are important. In the process of optimizing the professional formation of students-psychologists, along with other, more traditional types of work, we propose to use a set of metaphorical associative cards «Supervision». Work with respondents can be done in many ways. For example, we initially offer an interactive «Microphone» game, where participants can join the circle and, by choosing one card from the MAC «Supervision» deck, alternately send a conditional «microphone» and ask a question to their vis-a-vis (in the form of a kind of interview), relying on the image on the card, fol- 
lowing ahead of time certain themes of exercise, for example, «I am a future psychologist». Also, this exercise can be carried out with practicing psychologists, analyzing such questions as «Why did I choose a psychologist's profession?», "How should a professional psychologist and how do I respond to this image?», "What professional qualities do I value most of all?» and so on. This game can take a few minutes, but it is able to set up participants quickly for further work: «I am a psychologist». This type of work allows you to model and explore various processes, situations from the past, simulate possible events in the future, find metaphorical images of solutions to actual problems.

The simplest exercise that allows you to get acquainted with the proposed deck is the interpretation of the images of individual cards. In individual work, the investigator is asked to choose one card from the first part of the deck, which contains only drawings, and to tell that what thoughts and feelings arise when viewing or which there are memories of life. In group form of work, each participant can choose the next card in turn and continue to interpret the drawings.

It is also recommended to use cards from the first deck along with cards from the second deck, which contain words that characterize emotional states and experiences. This allows you to refine the content and deepen the analysis of interpretations that arise during work. We note that the combination of cards stimulates the development of imagination and fantasy, provides access to a integral picture of the personal «Me».

With the help of cards with images and words, you can carry out the "Unfinished Sentences» exercise. For example, the beginning of the phrase "Psychology for me is ...» and the participants are invited to continue the opinion, choosing cards from the first and the second logs. You can also use phrases such as «As for me the profession of a psychologist is ...», «The purpose of my profession is ...», "I believe that during the work there may be such difficulties as ...», "I will be able to help people through ...», "I will be able to become a good specialist because ...», "Now I am worried ...».

You can also use the coaching set of metaphorical associative cards «Supervision» for the development of professional psychological skills. The deck with pictures is proposed to be divided into two parts: cards that cause the participant positive feelings, and cards, which cause unacceptable, misunderstanding or negative emotions. 
After this it is necessary to find and characterize something positive in all the cards of the "negative» part and thus add them to the first part. Their opinion should be substantiated, defended and motivated, and not limited to the phrase: «I do not like».

Conclusion. Existing difficulties related to the professional formation of psychologists and the practice in this field indicate the need for work to optimize these processes. We believe that the application of such a new projective method of work as MAC, develops the ability to make decisions, increases emotional stability and professional self-awareness, improves reflection skills, etc. A practical tool for resolving the above-mentioned issues was our coaching set of metaphorical associative cards «Supervision», aimed at working with students-psychologists and practicing psychologists, and allows us to rely on the experience of the past, internal experiences and associations when working with it. The use of MAC promotes the deliberate disclosure of the inner world of each participant, the release of emotions, the presentation of thoughts, hiding in the subconscious, the definition of problem areas through the analysis of associative images, the awakening of internal resources to understanding the problems and finding ways to solve them further.

There are many forms and methods of working with MAC, because associative decks represent a kind of psychological mirror that reflects our actual states and experiences and allows us to know better ourselves and find answers to disturbing questions. There is no «limit» in working with them - they can be used daily in any situation that needs to be solved. With the help of our coaching deck of metaphorical associative cards «Supervision» we can conduct training for professionally important skills, develop the necessary qualities of a psychologist, and also reproduce situations that arise during the practical activities of a psychologist, which makes its use extremely important in the work of practicing and future specialists of psychological profile.

\section{Список використаних джерел}

1. Берн Э. Игры, в которые играют люди. Психология человеческих взаимоотношений. Люди, которые играют в игры. Психология человеческой судьбы / Э. Берн ; пер. с англ. А. Грузберга. - М. : Эксмо, 2012. - 352 с.

2. Попова Г. В. Алгоритмы применения метафорических ассоциативных карт в индивидуальном консультировании / Г. В. Попова, Н. Э. Милорадова // Актуальні напрямки 
сучасної практичної психології і психотерапії : матеріали міжнар. наук.-практ. конф. - Х. : ХНУВС, 2013. - С. 57-60.

3. Пряжников Н. С. Профессиональное и личностное самоопределение / Н. С. Пряжников. - М., 1996. - 256 с.

4. Фрейд 3. Психология бессознательного / З. Фрейд. - М. : Просвещение, 1990. - 448 с.

5. Шнейдер Л. Б. Профессиональная идентичность : монография / Л. Б. Шнейдер. - М. : МОСУ, 2001. - 272 с.

6. Юнг К. Подход к бессознательному / К. Юнг // Архетип и символ. - М. : Ренессанс, 1991. - 65 с.

\section{Spysok vykorystanyh dzherel}

1. BernJe. Igry, v kotoryeigrajutljudi. Psihologija chelovecheskih vzaimootnoshenij. Ljudi, kotorye igrajut v igry. Psihologija chelovecheskoj sud'by / Je. Bern ; per. s angl. A. Gruzberga. M. : Jeksmo, 2012. $-352 \mathrm{~s}$.

2. Popova G. V. Algoritmy primenenija metaforicheskih associativnyh kart v individual'nom konsul'tirovanii / G. V. Popova, N. Je. Miloradova // Aktual'ni naprjamky suchasnoi' praktychnoi' psyhologii' i psyhoterapii' : materialy mizhnar. nauk.prakt. konf. - H. : HNUVS, 2013. - S. 57-60.

3. Prjazhnikov N. S. Professional'noe i lichnostnoe samoopredelenie / N. S. Prjazhnikov. - M., 1996. - 256 s.

4. Frejd Z. Psihologija bessoznatel'nogo / Z. Frejd. - M. : Prosveshhenie, 1990. - 448 s.

5. Shnejder L. B. Professional'naja identichnost' : monografija / L. B. Shnejder. - M. : MOSU, 2001. - 272 s.

6. Jung K. Podhod k bessoznatel'nomu / K. Jung // Arhetip i simvol. - M. : Renessans, 1991. $-65 \mathrm{~s}$.

Received January 29, 2018

Revised February 16, 2018 Accepted March 9, 2018 